\title{
Wound healing activity of Chrysophyllum cainito L. leaves: Evaluation in rats using excision wound model
}

Sunita Shailajan* and Deepti Gurjar

Herbal Research Lab, Ramnarain Ruia College, Matunga (E), Mumbai 400019, INDIA.

\begin{abstract}
Background: The present study was aimed to evaluate the traditionally reported wound healing potential of Chrysophyllum cainito leaves. Methods: The ethanolic extract of $C$. cainito leaves was standardized in terms of its gallic acid content (a phenolic compound with wound healing properties) using a validated HPTLC technique. The antioxidant activity of $C$. cainito leaves was also evaluated in vitro. The wound healing potential of the extract was evaluated in male Albino Wistar rats using excision wound model. The results were statistically evaluated and compared with traditional drug Jatyadi Taila (JT) and modern drug Betadine (BTD). Results: Topical application of the standardized ethanolic extract of $C$. cainito leaves on excision wounds caused the significantly faster reduction in the wound area as compared to JT and BTD. Similarly, it also showed the significant increase in the tissue biochemical parameters such as hydroxyproline, hexosamine and protein when compared with the untreated control. Conclusion: Findings of the present study provide a baseline data on wound healing and antioxidant potential of $C$. cainito leaves and supports their traditional claim.
\end{abstract}

Key words: Antioxidant activity, Excision wound model, Gallic acid, Chrysophyllum cainito L. leaves, Efficacy.

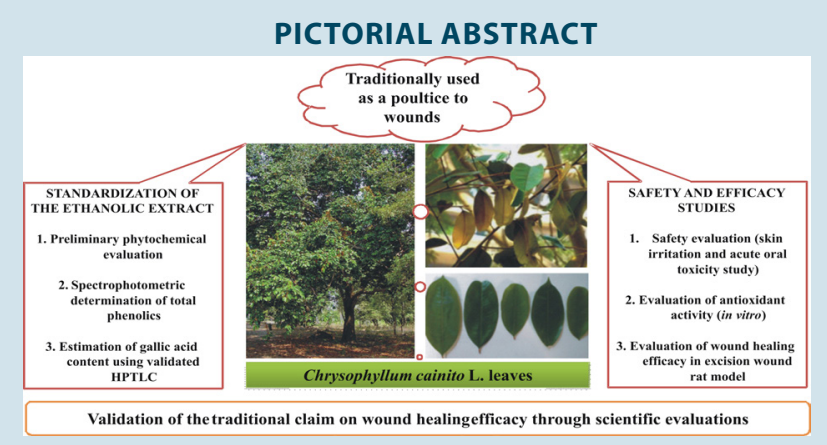

Correspondence :

Dr. Sunita Shailajan,

Head, Department of Botany and Incharge of Herbal Research Lab, Ramnarain Ruia College, Matunga (E), Mumbai-400019, INDIA.

Tel on: 022 24154390; Fax no: 02224142480

E-mail: sunitashailajan@gmail.com

DOI: 10.5530/jyp.2016.2.7

\section{INTRODUCTION}

Chrysophyllum Linn. (Sapotaceae), is a genus of evergreen trees, distributed mainly in the tropics, especially America with a few species in West Africa and Australia. Chrysophyllum cainito (C. cainito), commonly known as 'star apple, 'caimito, 'abiuroxo' or 'abiu-do-Para,, is one of the species native to West Indies. ${ }^{1}$ This plant is highly desired in tropics and cultivated throughout Southeast Asia, Caribbean, West tropical Africa, Zanzibar, Brazil and the warmer parts of India for its ornamental value and production of large edible fruits. ${ }^{1}$ There are several reports from folk medicine indicating that the bark, leaves, fruits and seeds of the Chrysophyllum genus present pronounced biological activity spectrum. ${ }^{2}$ Different parts of $C$. cainito like fruits, bark have been used as an antitussive, astringent, antioxidant agent, in the treatment of diarrhoea, fever, diabetes, gonorrhea, catarrh of the bladder and abscesses. ${ }^{1-4}$

The leaves of $C$. cainito are reported to possess some major groups of therapeutically active phytochemicals like alkaloids, sterols, triterpenes ${ }^{5}$ and also found to be a source of individual phytochemical constituents like myricetin, myricitrin. ${ }^{4}$ Shailajan and Gurjar $(2014)^{5}$ reported the presence of ursolic acid, $\beta$-sitosterol, lupeol, gallic acid for the first time from C. cainito leaves and quantitated using a validated HPTLC technique. The leaves of $C$. cainito are traditionally used in the treatment of diabetes and have been studied scientifically for their hypoglycemic activity in diabetic animal model. ${ }^{2}$ Recently, the leaves of $C$. cainito have been reported to possess anti-inflammatory and anti-hypersensitive activity. ${ }^{2}$ Traditionally, the leaves are also used as a poultice to a wound. ${ }^{6}$

A thorough literature survey revealed that, C. cainito is frequently used in folk medicine for the management of wide range of ailments, but there are very few scientific studies on the plant whether in relation to its chemical or its pharmacological aspects. Though $C$. cainito leaves have been used in the management of wounds traditionally, there is a dearth of scientific data on the evaluation of their wound healing potential. In a view of the fact that the reported bioactive phytochemical constituents and anti-inflammatory activity possessed by C. cainito leaves may also assist in their wound healing potential, in the present research work, an attempt has been made to evaluate the wound healing activity of the standardized ethanolic extract of $C$. cainito leaves using excision wound model. Three different doses of the ethanolic extract of $C$. cainito leaves were compared with traditional drug Jatyadi Taila (JT) and modern drug Betadine (BTD) along with natural recovery (normal/ untreated control) and vehicle control. In order to support the traditional use of $C$. cainito leaves as a wound healing agent, various parameters were evaluated including percent wound contraction, epithelialization period, hydroxyproline, hexosamine and protein content of granulation tissue and histopathological observations. In addition, the antioxidant activity of the standardized ethanolic extract of $C$. cainito leaves was evaluated in vitro.

\section{MATERIALS AND METHODS}

\section{Plant materials}

C. cainito leaves were collected from Matunga, and their taxonomic identification was confirmed by Agharkar Research Institute, Pune (Authentication no. 13-020). The leaves were shade dried for a week followed by drying in an oven preset at $37^{\circ} \mathrm{C}$ for four days. The sample was powdered in a mixer grinder, sieved ( 85 mesh, BSS) and stored in an airtight container.

\section{Chemicals and reagents}

Gallic acid (98 \% purity, Figure 1), DPPH, and Galvinoxyl were procured from Sigma-Aldrich Chemical Company, (Steinheim, Germany). Glycol stearate, 1, 2-propylene glycol and liquid paraffin used to prepare vehicle base for the ointment and other chemicals of analytical grade 


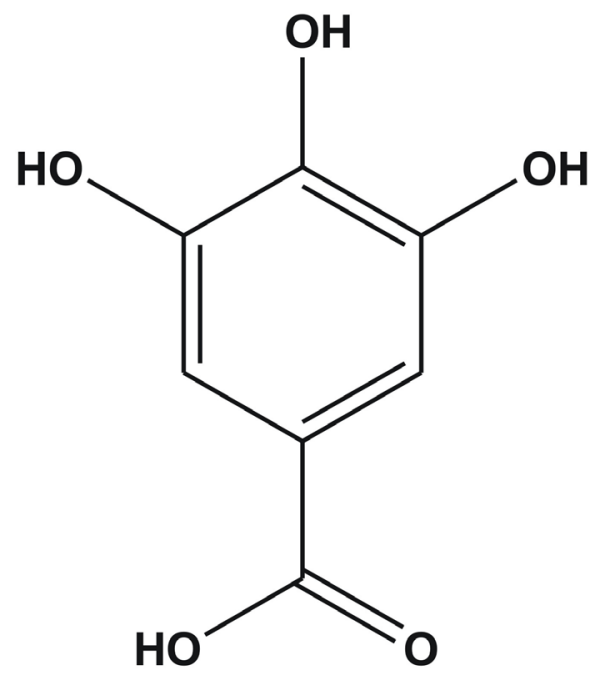

Figure 1: Structure of gallic acid

were purchased from Merck Specialties Pvt. Ltd., Mumbai. Topical antibiotic ointment formulation BTD (G. S. Pharmbutor Pvt. Ltd., Uttarakhand) and traditional drug JT (Shree Baidyanath Ayurved Bhawan Pvt. Ltd., Nagpur) purchased from the market were used as positive controls for the wound healing evaluation. LOX 10\% Spray (Lidocaine Topical Aerosol, Neon Laboratories Ltd., Mumbai) was used as a local anesthetic agent during wound healing study.

\section{Preparation of the ethanolic extract from C. cainito leaves and standardization}

Accurately weighed powdered C. cainito leaves (500 g) were extracted with ethanol $(51 \times 3)$ under reflux for $6 \mathrm{~h}$ followed by filtration through Whatman filter paper no. 1 . The filtrate was evaporated under reduced pressure at $40^{\circ} \mathrm{C}$ to obtain the ethanolic extract. Chemical standardization of the ethanolic extract was carried out by performing preliminary phytochemical tests for the presence of flavonoids, essential oils, phenolics, glycosides, alkaloids and resins as per the reported method. ${ }^{5}$ In addition, the extract was also subjected for evaluation of its total phenolics content as per the method reported. ${ }^{7}$ The ethanolic extract of $C$. cainito leaves was also standardized in terms of its gallic acid content [a phenolic compound with wound healing potential $\left.{ }^{8}\right]$ using our recently published validated HPTLC technique. ${ }^{5}$

\section{Antioxidant activity}

Antioxidant activity of the standardized ethanolic extract of C. cainito leaves was evaluated in vitro using two stable free radicals, 2, 2-Diphenyl-1picrylhydrazyl (DPPH) ${ }^{9}$ and galvinoxyl. ${ }^{7}$ The total ferric chloride reducing power of the standardized extract was also determined. ${ }^{10}$ Ascorbic acid was used as a reference standard.

\section{Experimental animals}

Acute oral toxicity and wound healing activity of the standardized ethanolic extract of $C$. cainito leaves was studied in male Albino Wistar rats (200-250 g) while female New Zealand Albino rabbits (1.3-1.7 kg) were used for the skin irritation study. All the animals were procured from Haffkine Biopharmaceuticals, Mumbai and were housed in polypropylene cages under standard experimental conditions with $26 \pm 2{ }^{\circ} \mathrm{C}$ ambient temperature and $12 \mathrm{~h}$ light-dark cycle. The animals were fed standard pellet diet (Amrut laboratory animal feed, India) and were provided water ad libitum.

\section{Formulation of the extract}

In order to formulate the ethanolic extract of $C$. cainito leaves into an ointment, the base (vehicle) was prepared using glycol stearate; 1,2- propylene glycol and liquid paraffin $(3: 6: 1 \mathrm{w} / \mathrm{v} / \mathrm{v})$ as described previously. ${ }^{11}$ The mixture was heated at $60^{\circ} \mathrm{C}$ with constant and gentle stirring, till glycol stearate completely dissolved. The mixture was cooled at room temperature with constant stirring till the white colored base of semisolid consistency achieved. The ethanolic extract of $C$. cainito leaves was triturated with the vehicle using a mortar pestle in order to prepare three different doses as low dose 2.5\% (CCL), mid dose 5\% (CCM) and high dose $20 \%(\mathrm{CCH})$. The test ointment $(0.5 \mathrm{~g}$ each) was applied topically on the wound site.

\section{Safety evaluation of the standardized ethanolic extract of $C$. cainito leaves}

Skin irritation test

In order to evaluate the safety of the standardized ethanolic extract of C. cainito leaves, skin irritation study as per OECD guidelines no. 404 was conducted on three female healthy rabbits. The study was approved from the Institutional Animal Ethics Committee (CPCSEA/315, approval no.: DG-130624-01). Approximately $24 \mathrm{~h}$ before the test, fur was removed by closely clipping the right/left area on the dorsal side of each rabbit. Ethanolic extract of $C$. cainito leaves (20\%) was applied neat on the patch at the right side (test), while the patch on left side was selected as control (without application of the extract). Observations for irritation in terms of erythema and edema were recorded after $24 \mathrm{~h}$, $48 \mathrm{~h}$, and $72 \mathrm{~h}$ of topical application. The results obtained were analyzed to determine the primary irritation index as described previously. ${ }^{12-14}$

\section{Acute oral toxicity study}

Acute oral toxicity study of the ethanolic extract of $C$. cainito leaves was conducted in male Albino Wistar rats ( $n=5 /$ group) as per OECD test guidelines no. $420 .{ }^{15-16}$ The study was approved from the Institutional Animal Ethics Committee (CPCSEA/315, approval no.: DG-130624-02). The rats were fasted for 10-14 h overnight and orally administered with the standardized ethanolic extract of $C$. cainito leaves in distilled water ( $2 \mathrm{~g} / \mathrm{kg}$ body weight). The animals were observed individually during the first $30 \mathrm{~min}$ for all reflexes, periodically during the first $48 \mathrm{~h}$ with special attention given during the first $4 \mathrm{~h}$ (short-term toxicity) and daily thereafter for a total of 14 days (long-term toxicity) for alteration from 
general behavior and clinical symptoms like alteration of skin and fur texture, ptosis, excessive salivation, breathing problems, diarrhea etc. Daily body weight, food and water intake record was also maintained. The results were compared with the control group (orally administered with distilled water).

\section{Wound healing evaluation of the standardized ethanolic extract of $C$. cainito leaves}

\section{Excision wound model}

The wound healing study of the standardized ethanolic extract of C. cainito leaves was approved from the Institutional Animal Ethics Committee (CPCSEA/315, approval no.: DG-130624-03). The rats were divided into six groups of six animals each and housed in groups of three per cage. The dorsal side of each animal was depilated and local anesthesia was given using 10\% lidocaine. One wound each (circular, $1 \mathrm{~cm}$ diameter) was made towards both flanks using punch biopsy tool and the wounds were kept open. The wounding day was considered as day zero. The animals of vehicle control groups were treated with base only. The test ointments were applied topically on the wound site. In all the groups, left-side wound was considered as untreated control while the right-side wound was treated as follows; group I: Vehicle base $(0.5 \mathrm{~g} /$ wound); group II-IV: CCL, CCM and $\mathrm{CCH}$, respectively ( $0.5 \mathrm{~g} /$ wound); group V: JT (0.75 mL/wound $)^{14}$; group VI: BTD $(0.5 \mathrm{~g} /$ wound $) .{ }^{17}$

\section{Wound area and wound contraction}

Application of the test samples (three different doses of plant extracts, reference drugs, and vehicle) was done on each day in the morning till the last day of the treatment. Daily evaluation of wound area with the photographic records was done from day one till the day of complete healing. Progressive changes in the wound area were measured planimetrically by tracing wound margin on graph paper every day. ${ }^{14}$ Wound contraction was calculated as percent reduction in the wound area. A parallel group of animals were wounded with excision wounds and treated similarly as described above. From this parallel group of treated animals, the granulation tissue (scab) was removed on the $5^{\text {th }}$ day post-wounding from respective patches. Biochemical evaluations were made using the granulation tissue samples. Daily body weight, food and water intake record of all the animals was also maintained.

\section{Estimation of biochemical parameters and epithelialization period}

Hydroxyproline and hexosamine content of granulation tissue was determined as per the reported methods. ${ }^{14}$ The protein content of granulation tissue was estimated by using Biuret method. ${ }^{14}$ The number of days required for falling off the dead tissue remnants without any residual raw wound was considered as the period of epithelialization. ${ }^{17}$

\section{Histopathology}

On the $5^{\text {th }}$ day post-wounding, the excised granulation tissue (scab) was also embedded in paraffin wax and serial sections ( $5 \mu \mathrm{m}$ thickness) were cut. These sections were stained with hematoxylin and eosin and were examined under light microscope. Ulceration, necrosis, epithelialization, congestion, edema, polymorphonuclear leukocytes (PNL), mononuclear cells, fibroblasts, and vascularization were qualitatively graded. ${ }^{14}$

\section{Statistical analysis}

GraphPad Prism software 5 version 5.03 (GraphPad Software, Inc., California, USA) was used to statistically evaluate the results. Data is represented as the arithmetic mean and standard error (Mean $\pm \mathrm{SE}$ ). In addition, the statistical significance of the results has been evaluated using one-way ANOVA and Tukey's test. All the differences were considered statistically significant if $\mathrm{p}<0.05$.

\section{RESULTS AND DISCUSSION}

In today's scenario, any symptoms of acute or chronic pain are considered a public health problem and wounds are considered to be one of them. ${ }^{2}$ Wound healing, the body's natural process of regenerating dermal and epidermal tissue, is the interaction of a complex cascade of cellular and biochemical actions leading to the restoration of structural and functional integrity. ${ }^{11}$ The synthetic drugs available for the treatment of wounds are either bacteriostatic or bactericidal, and in these cases healing may be by natural phenomenon. In addition, these synthetic drugs are not only expensive but also pose problems such as allergy, drug resistance etc. ${ }^{18}$ This situation has forced scientists to seek alternative drugs for the treatment of wounds.

Nature has been a source of medicinal treatments for thousands of years and plant-based systems continue to play an essential role in the preliminary health care. Plants have the immense potential for the management and treatment of wounds. These natural agents induce healing and regeneration of the lost tissue by multiple mechanisms. ${ }^{19}$ Therefore, screening of plant-based drugs in terms of phytochemical composition is an inevitable part to underpin their use as a wound healing agent.

A large number of plants are used by tribal and folklore in many countries for the treatment of wounds, but validation of the traditional claims through scientific studies is an indispensable part for their global acceptance as potential wound healing agents. Therefore, in this study the $C$. cainito leaves have been evaluated for their wound healing potential in Albino Wistar rats using excision wound model in order to support and validate their traditional claim. The findings have also been supported by determining the content of total phenolics and gallic acid (a phenolic compound with wound healing properties) from the extract and evaluating its antioxidant property.

\section{Standardization of the ethanolic extract of C. cainito leaves}

Extraction of $C$. cainito leaves using ethanol gave a dark green colored residue (yield: $4.73 \%$ ). During the qualitative preliminary phytochemical evaluation, resins and phenolics were found to be present in the ethanolic extract of C. cainito leaves. The extract showed total phenolics content of $76.2 \pm 0.12 \mathrm{mg} \mathrm{GAE} / \mathrm{g}$ of dried extract. Our recently published validated HPTLC technique on the estimation of gallic acid from plant samples was successfully used for the chemical standardization of the ethanolic extract of $C$. cainito leaves and the content of gallic acid was found to be $5.92 \pm 0.007 \mathrm{mg} / \mathrm{g}$ of dried extract. Similarly, the ethanolic extract of Emblica officinalis fruits ${ }^{20}$ and Agaricus bisporus ${ }^{21}$ has also been standardized in terms of gallic acid content prior to their pharmacological evaluation. The content of gallic acid in the ethanolic extract of C. cainito leaves was found to be more when compared with these published reports.

\section{Standardized ethanolic extract of $C$. cainito leaves as an antioxidant agent}

The overproduction of reactive oxygen species (ROS) and oxygenderived free radicals often contribute to the variety of pathological effects and induce many diseases like cancer, atherosclerosis, diabetes and rheumatoid arthritis. ${ }^{7}$ The oxidative stress also plays an important role in impaired wound healing. The ROS produced at the wound site if present at high concentrations, can induce severe tissue damage, lead to neoplastic transformation, and even decrease the healing process by damaging the cellular membranes, DNA, proteins, and lipids. ${ }^{22,23}$ Antioxidants can interfere with the oxidation process by reacting with free radicals, chelating catalytic metals and by acting as oxygen scavengers. Plants constitute the richest source of natural antioxidants to 
Table 1: Antioxidant activity of the standardized ethanolic extract of $C$. cainito leaves expressed in $I C_{50}(\mu g / m L)$ for DPPH and galvinoxyl free radical assay and $\mathrm{EC}_{50}(\mu \mathrm{g} / \mathrm{mL})$ for reducing power assay

\begin{tabular}{cccc}
\hline Sample & DPPH radical & Galvinoxyl radical & Reducing power \\
\hline Standardized ethanolic extract of $\boldsymbol{C}$. cainito leaves & $44.72 \pm 0.020$ & $54.75 \pm 0.027$ & $143.68 \pm 0.743$ \\
Ascorbic acid & $2.29 \pm 0.004$ & $1.54 \pm 0.002$ & $31.43 \pm 0.012$ \\
\hline
\end{tabular}

\begin{tabular}{|c|c|c|c|c|}
\hline \multirow[b]{2}{*}{ Groups } & \multicolumn{4}{|c|}{ Parameters } \\
\hline & $\begin{array}{l}\text { Hydroxyproline content } \\
(\mathrm{mg} / \mathrm{g})\end{array}$ & $\begin{array}{c}\text { Hexosamine Content } \\
(\mathrm{mg} / \mathrm{g})\end{array}$ & $\begin{array}{c}\text { Protein content } \\
(\mathrm{mg} / \mathrm{g})\end{array}$ & $\begin{array}{l}\text { Epithelialization period } \\
\text { (in days) }\end{array}$ \\
\hline NC & $20.035 \pm 0.5607$ & $2.195 \pm 0.0716$ & $22.347 \pm 0.2584$ & $12.08 \pm 0.239$ \\
\hline VC & $21.908 \pm 0.3653$ & $2.328 \pm 0.1436$ & $23.137 \pm 0.1914$ & $11.92 \pm 0.239$ \\
\hline CCL & $52.242 \pm 0.2208^{\mathrm{a}}$ & $5.547 \pm 0.1461^{\mathrm{a}}$ & $43.528 \pm 0.1582^{\mathrm{a}}$ & $11.08 \pm 0.154^{\mathrm{a}}$ \\
\hline CCM & $61.635 \pm 0.4480^{\mathrm{a}}$ & $7.070 \pm 0.1335^{\mathrm{a}}$ & $74.312 \pm 0.1582^{\mathrm{a}}$ & $9.33 \pm 0.167^{a}$ \\
\hline $\mathrm{CCH}$ & $78.908 \pm 0.6777^{\mathrm{a}}$ & $9.372 \pm 0.2046^{\mathrm{a}}$ & $81.565 \pm 0.1175^{\mathrm{a}}$ & $8.00 \pm 0.183^{\mathrm{a}}$ \\
\hline $\mathrm{JT}$ & $64.313 \pm 0.5270^{\mathrm{a}}$ & $7.425 \pm 0.1748^{\mathrm{a}}$ & $69.413 \pm 0.3221^{\mathrm{a}}$ & $10.00 \pm 0.183^{a}$ \\
\hline BTD & $63.063 \pm 0.4432^{\mathrm{a}}$ & $7.030 \pm 0.0976^{a}$ & $72.753 \pm 0.3131^{\mathrm{a}}$ & $10.08 \pm 0.154^{\mathrm{a}}$ \\
\hline
\end{tabular}

NC: Normal/untreated control, VC: Vehicle control (base), CCL: Low dose of the standardized ethanolic extract of C. cainito leaves (2.5\%), CCM: Mid dose of the standardized ethanolic extract of C. cainito leaves (5\%), CCH: High dose of the standardized ethanolic extract of C. cainito leaves (20\%), JT: Jatyadi Taila (traditional drug), BTD: Betadine (modern drug). Data expressed as mean $\pm \mathrm{SE}, \mathrm{n}=6 .{ }^{\mathrm{a}} \mathrm{p}<0.001$ when compared with control group (NC).

counteract ROS. ${ }^{22,23}$ Various plants have been reported to possess both antioxidant and wound healing properties. ${ }^{22,23}$ Therefore, the overall role of antioxidants appears to be significant in the successful management and treatment of wounds.

In this study, the antioxidant potential of the standardized ethanolic extract of C. cainito leaves was evaluated in vitro in terms of free radical scavenging activity and ferric chloride reducing power. The $\mathrm{IC}_{50}$ value of the standardized ethanolic extract of $C$. cainito leaves was found to be less for DPPH free radical when compared with galvinoxyl free radical. The results have been summarized in Table 1 . The results clearly suggest that the standardized ethanolic extract of $C$. cainito leaves could transfer its protons to both the free radicals and donate electrons to ferric ions which finally terminate the free radical reaction. ${ }^{23}$ Like fruits of C. cainito, the antioxidant activity shown by $C$. cainito leaves may be attributed to the presence of gallic acid and other phenolic compounds which are reported as potent antioxidant agents., ${ }^{3,21}$ Similar results have been reported for the ethanolic extract of Mimosa pudica leaves ${ }^{24}$ and different plant parts of Lepidium sativum. ${ }^{25}$

\section{Safety of the standardized ethanolic extract of $C$. cainito leaves}

Skin irritation test of the standardized ethanolic extract of C. cainito leaves $(20 \%)$ on rabbits showed no signs of dermal irritation after the topical application. The Primary Irritation Index of the standardized ethanolic extract of C. cainito leaves was found to be 0.00 (Appendix 1: Supplementary material). Thus, it was confirmed that the standardized ethanolic extract of $C$. cainito leaves has an adequate safety margin to be used on rabbit skin. In addition, oral administration of the standardized ethanolic extract of $C$. cainito leaves to rats did not cause any mortality as well as no significant change in the body weight, food and water intake was observed when compared with the animals of the control group. The cage-side observations were also appeared normal (Appendix 2: Supplementary material). Thus, the data obtained from the skin irritation study and acute oral toxicity study may ensure an adequate safety margin of C. cainito leaves for their intended use.

\section{Wound healing potential of the standardized ethanolic extract of $C$. cainito leaves}

Wound contraction, which contributes to wound closure, is expressed as a reduction in the percentage of the original wound size. The topical application of the standardized ethanolic extract of $C$. cainito leaves at three different doses significantly increased $(p<0.001)$ the rate of wound contraction when compared with the animals of control groups (Figure $2 \mathrm{a}$ and $2 \mathrm{~b}$ ). The highest dose of the standardized ethanolic extract of C. cainito leaves (CCH-20\%) showed the fastest rate of wound closure with complete healing on the $10^{\text {th }}$ day post-wounding. The complete wound closure by CCM-5\% was observed on the $11^{\text {th }}$ day, by JT and BTD on the $12^{\text {th }}$ day and by CCL- $2.5 \%$ on the $13^{\text {th }}$ day post-wounding (Figure $2 \mathrm{a}$ and $2 \mathrm{~b}$ ). During the study, no significant change in the body weight, food and water intake of all the animals was observed. As per the observations made, the study indicated dose-dependent nature of the standardized ethanolic extract of $C$. cainito leaves to induce cellular proliferation, rapid epithelialization, and collagenization, and the dose of $20 \%$ may be considered potentially useful to obtain significant wound healing activity.

The injured skin remains vulnerable to invasive microbial infections of all kinds of subsequent development of wound sepsis until the complete epithelial repair has occurred. ${ }^{22}$ Therefore, cell proliferation is an essential event during re-epithelialization, so as the proliferating keratinocytes ensure an adequate supply of cells to migrate and cover the wound. ${ }^{26}$ In the present study, it was observed that the epithelialization period was not significantly different when animals from normal (untreated) and vehicle control groups were compared (Table 2). On the contrary, the epithelialization period was significantly reduced in the animals treated with the highest dose of the standardized ethanolic extract of $C$. cainito leaves when compared with the animals from the control group. This suggests that the extract may exert a positive effect towards cellular proliferation. Animals from the other treatment groups also showed a significant reduction in the epithelialization period $(p<0.001)$ when compared with the animals of the control group (Table 2). Thus, the standardized ethanolic extract of $C$. cainito leaves exert wound healing potential in 


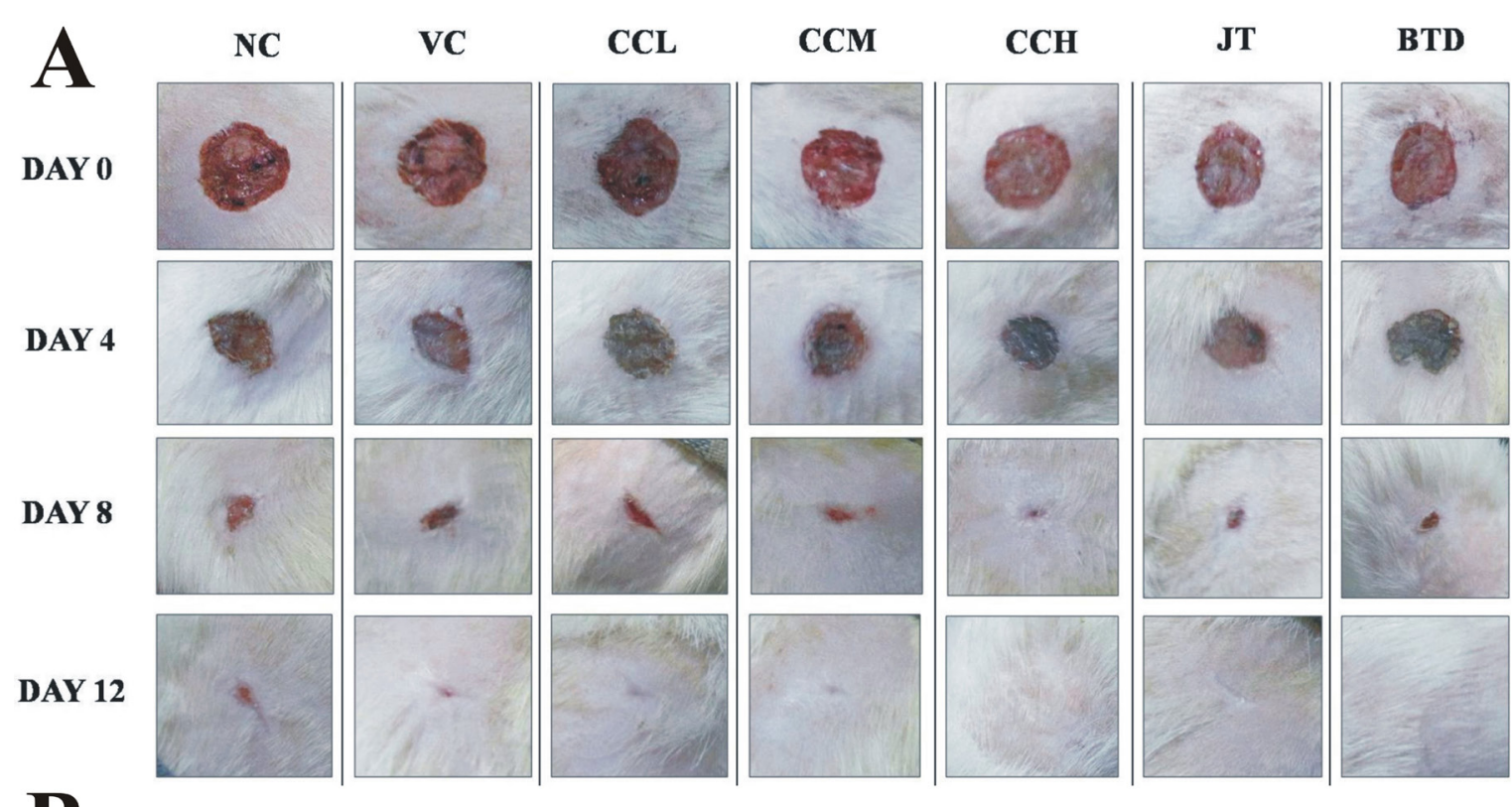

B

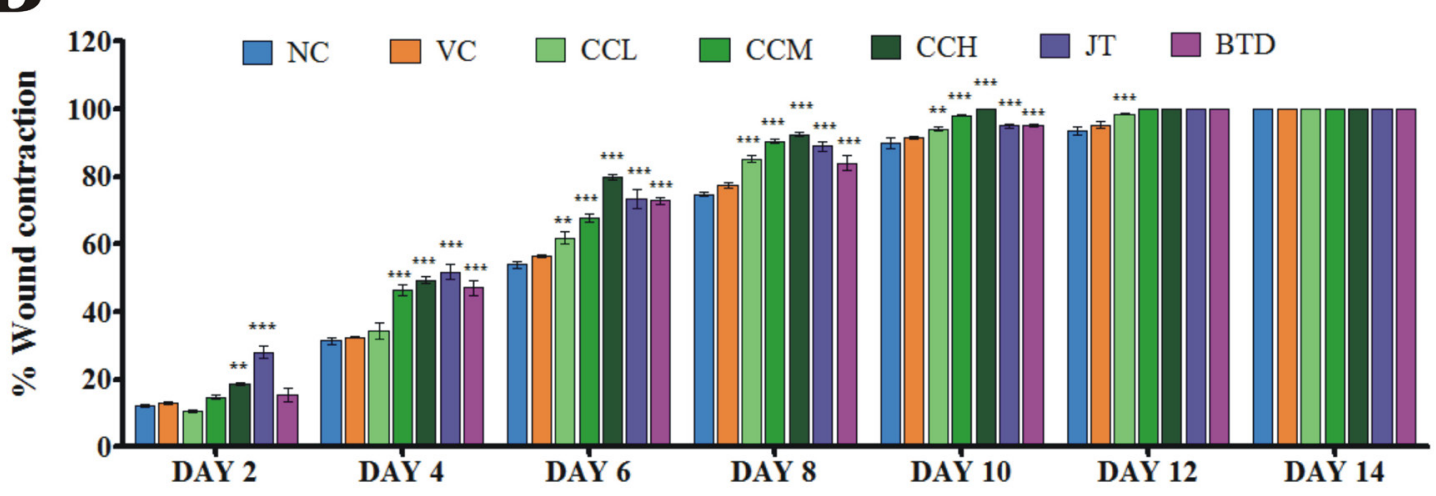

Figure 2: Effect of C. cainito leaves on wound contraction in excision wound rat model: photographic record (A) and percent wound contraction (B) NC: Normal/ untreated control, VC: Vehicle control (base), CCL: Low dose of the standardized ethanolic extract of C. cainito leaves (2.5\%), CCM: Mid dose of the standardized ethanolic extract of C. cainito leaves (5\%), CCH: High dose of the standardized ethanolic extract of C. cainito leaves (20\%), JT: Jatyadi Taila (traditional drug), BTD: Betadine (modern drug). Data expressed as mean $\pm \mathrm{SE}, \mathrm{n}=6 .{ }^{* *} \mathrm{p}<0.01$ and ${ }^{* * *} \mathrm{p}<0.001$ compared to the control group (NC) on respective day.

rats with excision wounds by significantly increasing the rate of wound contraction and reducing the period of epithelialization.

Hydroxyproline, hexosamine, and protein are the biomarkers which indicate the rate of wound healing and collagen turnover. ${ }^{14,27}$ Hydroxyproline, the collagen composed of an amino acid is the major component of extracellular tissue which plays an important role in hemostasis and gives strength and support. During wound repair, fibroblasts migrate from the wound edges to the wound site, proliferate, and subsequently produce collagen. The determination of hydroxyproline content hence can be used as an index for collagen turnover. ${ }^{22}$ Hexosamine, synthesized by fibroblasts in the wound area are matrix molecules which act as a ground substratum for extracellular matrix, on which the collagen can be laid. ${ }^{14}$ Wounds treated with the highest dose of the standardized ethanolic extract of C. cainito leaves showed significant increase in the content of hydroxyproline, hexosamine and protein of the granulation tissue (scab) as compared with control wounds, (Table 2, $\mathrm{p}<0.001$ ). The significant increase in hydroxyproline content of scab tissue after application of the standardized ethanolic extract of $C$. cainito leaves may be attributed to the increase in collagen concentration and stabilization of fibers. ${ }^{17}$ Whereas, significant increase in the protein content of dry granulation tissue from the wounds treated with the standardized ethanolic extract of $C$. cainito leaves indicates the cellular proliferation. ${ }^{28}$

Newly synthesized collagen at the wound site increases the tensile strength of the wound tissue. Histopathological evaluation of wound tissue after the treatment of excision wounds with the standardized ethanolic extract of $C$. cainito leaves revealed increased cellular proliferation and marked collagenization which might have significantly contributed to the healing process (Appendix 3: Supplementary material). Epithelialization was evident in all the groups including normal/untreated control group but with a marked recovery of tissue in animals treated with the highest dose of the standardized ethanolic extract of $C$. cainito leaves. None of the treatment regimens induced necrosis on the wound area. Similar results have been reported for the ethanolic extract of Acacia caesia bark, ${ }^{26}$ Calotropis procera bark, ${ }^{29}$ Curcuma longa rhizomes. ${ }^{30}$

This is the first attempt to evaluate the wound healing activity of the standardized ethanolic extract of C. cainito leaves. Findings of this study, confirm that the rate of wound contraction was significantly higher and period of epithelialization was shorter in rats treated with the standardized ethanolic extract of $C$. cainito leaves. The topical administration of the standardized ethanolic extract of $C$. cainito leaves facilitated various 
stages of wound healing such as fibroplasia, collagen synthesis, wound contraction, and epithelialization. The significant increase in biochemical parameters (hydroxyproline and hexosamine) of the granulation tissue from the excision wound animal model indicates cellular hyperplasia. Similarly, there is an increase in the total protein content representing the active synthesis and deposition of matrix proteins in the granulation tissues which is also supported by the observations made during the histopathological evaluation of granulation tissue. Thus, results obtained in this study validate the traditional claim on wound healing efficacy of C. cainito leaves. Indeed, it is equally essential to evaluate these leaves using some other wound models such as incision wound, burn wound, etc.

\section{CONCLUSION}

C. cainito leaves, like various other plants, have been traditionally used in the treatment of wounds, but the credence of the use of leaves as a wound healing agent is entirely based upon their validation through scientific study. This study, therefore, provides a basis to the traditional use of
C. cainito leaves as wound healing agent. Present work is the first attempt in evaluating the wound healing potential of the standardized ethanolic extract of C. cainito leaves as well as evaluation of its antioxidant potential. The standardized ethanolic extract of $C$. cainito leaves shows a great potential to be developed into an ointment or gel for its topical use in the management of wounds. Findings of the present study also provide the basis for designing further investigations on the therapeutic action of the standardized ethanolic extract of $C$. cainito leaves especially to evaluate wound healing efficacy in diabetic as well as in chronic ulcers.

\section{ACKNOWLEDGEMENT}

Authors acknowledge the help of Bhavesh Tiwari, Gauri Swar, Archana Matani, Dipti Singh, Mayuresh Joshi and Anjali Lade during the animal studies.

\section{CONFLICTS OF INTEREST}

None declared.

\section{ABBREVIATIONS USED}

ANOVA: Analysis of variance; BSS: British Standard Sieve; BTD: Betadine; CCH: High dose of the standardized ethanolic extract of C. cainito leaves (20\%); CCL: Low dose of the standardized ethanolic extract of $C$. cainito leaves $(2.5 \%)$; CCM: Mid dose of the standardized ethanolic extract of $C$. cainito leaves (5\%); CPCSEA: Committee for the Purpose of Control and Supervision of Experiments on Animals; DNA: Deoxyribonucleic acid; DPPH: 2, 2-diphenyl-1-picrylhydrazyl; $\mathbf{E C}_{50}$ : Half maximal effective concentration; GAE: Gallic acid equivalent; HPTLC: High Performance Thin Layer Chromatography; IC ${ }_{50}$ : Half maximal inhibitory concentration; JT: Jatyadi Taila; NC: Normal control; OECD: Organization for Economic Co-operation and Development; PNL: Polymorphonuclear leukocytes; ROS: Reactive oxygen species; SE: Standard error; VC: Vehicle control.

\section{ABOUT AUTHORS}

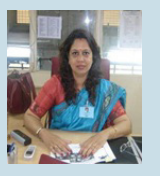

Dr. Sunita Shailajan: Is Head, Department of Botany, Incharge of Herbal Ressearch Lab and Scientist Incharge of Animal Testing Centre at Ramnarain Ruia College affiliated to University of Mumbai, Maharashtra, India. She is a recognized research guide in the subject of Botany, Bioanalytical Sciences, Biotechnology and Applied Biology. Her specialization is in the area of standardization of herbal raw materials/medicinal plants and ASU formulations, instrumentation (HPTLC and HPLC), analytical and bioanalytical method validation and toxicological, pharmacological and pharmacokinetic studies. She has more than 90 scientific publications in this area and made presentations in various National and International conferences in India and overseas. She has been working as a Principal Investigator for Government funded projects and has been appointed as a reviewer for various National and International high repute journals.

Ms. Deepti Gurjar: Is a Ph.D. student in Bioanalytical Sciences at Ramnarain Ruia College, affiliated to University of Mumbai, Maharashtra India. She has completed M.Sc. in the subject of Bioanalytical Sciences at Birla College, University of Mumbai. She is pursuing her Ph.D. and also working as a Junior Research Fellow on the project funded by Department of Biotechnology, Government of India in the area of standardization of some medicinal plants and evaluation of their therapeutic efficacies. She has six publications and presented her work in this field at National and International Conferences.

\section{REFERENCES}

1. Parker IM, Lopez I, Petersen JJ, Anaya N, Cubilla Rios L, Potter D. Domestication Syndrome in Caimito (Chrysophyllum cainito L.): Fruit and Seed Characteristics. Econ Bot. 2010;64(2):161-75.

2. Meira NA, Klein Jr LC, Rocha LW, Quintal ZM, Monache FD, Filho VC, et al. Anti-inflammatory and anti-hypersensitive effects of the crude extract, fractions and triterpenes obtained from Chrysophyllum cainito leaves in mice. J Ethnopharmacol. 2014;151(2):975-83.

3. Luo XD, Basile MJ, Kennelly EJ. Polyphenolic antioxidants from the fruits of Chrysophyllum cainito L. (Star Apple). J Agric Food Chem. 2002;50(6):137982.

4. The Wealth of India. A dictionary of Indian raw materials and industrial products raw materials. Volume 3. New Delhi: Publication and Information Directorate; 1992. p. 519-20.

5. Shailajan S, Gurjar D. Pharmacognostic and phytochemical evaluation of Chrysophyllum cainito Linn. leaves. Int J Pharm Sci Rev Res. 2014;26(1):106-11.

6. Worldagroforestry.org [homepage on the Internet]. Nairobi: Agroforestry Database. [updated 2015; cited Sept 30. Available at http://www.worldagroforestry. org/treedb2/speciesprofile.php? Spid=524.

7. Ling LT, Yap SA, Radhakrishnan AK, Subramaniam T, Cheng HM, Palanisamy $\cup$. Standardised Mangifera indica extract is an ideal antioxidant. Food Chem. 2009;113(4):1154-59.
8. Bigoniya P, Agrawal S, Verma N. Potential wound healing activity of Euphorbia hirta Linn total flavonoid fraction. Int J Pharm Sci Rev Res. 2013;22(2):149-56.

9. Narendhirakannan RT, Rajeshwari K. In vitro antioxidant properties of three varieties of Allium sativum L. extracts. E-J Chem. 2010;7(1):573-9.

10. Marathe SA, Rajalakshmi V, Jamdar SN, Sharma A. Comparative study on antioxidant activity of different varieties of commonly consumed legumes in India. Food Chem Toxicol. 2011;49(9):2005-12.

11. Renda G, Yalcin FN, Nemutlu E, Akkol EK, Suntar I, Keles H, et al. Comparative assessment of wound healing potentials of various Trifolium L. extracts and determination of their isoflavone contents as potential active ingredients. J Ethnopharmacol. 2013;148(2):423-32.

12. Organization of Economic Co-operation and Development. 2004. Guidelines for Testing of Chemicals. No. 404. Acute Dermal Irritation/Corrosion, Paris.

13. Shailajan S, Wadke P, Joshi H, Tiwari B. Evaluation of quality and efficacy of an ethnomedicinal plant Ageratum conyzoides L. in the management of pediculosis. J Young Pharm. 2013;5(4):139-43.

14. Shailajan S, Menon S, Pednekar S, Singh A. Wound healing efficacy of Jatyadi Taila: In vivo evaluation in rat using excision wound model. J Ethnopharmacol. $2011 ; 138(1): 99-104$

15. Organization for Economic Cooperation and Development. 2001. Guidelines for Testing of Chemicals. No. 420. Acute Oral Toxicity- Fixed Dose Procedure, Paris. 
16. Parasuraman S. Toxicological screening. J Pharmacol Pharmacother. 2011; 2(2):74-9.

17. Subramoniam A, Evans DA, Rajasekharan S, Nair SG. Effect of Hemigraphis colorata (blume) H. G. Hallier leaf on wound healing and inflammation in mice. Indian J Pharmacol. 2001;33(4):283-5.

18. Sabale P, Bhimani B, Prajapati P, Sabale V. An overview of medicinal plants as wound healers. Journal of Applied Pharmaceutical Sciences. 2012;2(11):143-50.

19. Narendhirakannan RT, Nirmala JC, Caroline A, Lincy S, Saj M, Durai D. Evaluation of antibacterial, antioxidant and wound healing properties of seven traditional medicinal plants from India in experimental animals. Asian Pac J Trop Biomed. 2012;2(3):S1245-S1253

20. Nigam N, Kejariwal M. Gallic acid content and antioxidant activity of the dried fruit and the processed fruit of Amla-Emblica officinalis L. Global Journal for Research Analysis. 2014;3(6):17-20.

21. Liu J, Jia L, Kan J, Jin Chang-hai. In vitro and in vivo antioxidant activity of ethanolic extract of white button mushroom (Agaricus bisporus). Food Chem Toxicol. 2013;51:310-6.

22. Thakur $R$, Jain N, Pathak $R$, Sandhu SS. Practices in wound healing studies of plants. Evid Based Complement Alternat Med. 2011;2011:1-17(Article 438056).

23. Suntar I, Akkol EK, Nahar L, Sarker S. Wound healing and antioxidant properties; do they coexist in plants?. Free Radicals and Antioxidants. 2012;2(2):1-7.
24. Azam S, Huda AF, Shams K, Ansari P, Mohamed MK, Hasan MM, et al. Antiinflammatory and anti-oxidant study of ethanolic extract of Mimosa pudica. J Young Pharm. 2015;7(3):234-40.

25. Malar J, Chairmanb K, Singh ARJ, Vanmathid JS, Balasubramaniana A, Vasanthie K. Antioxidative activity of different parts of the plant Lepidium sativum Linn. Biotechnol Rep. 2014;3:95-8.

26. Suriyamoorthy S, Subramaniam K, Durai S JR, Wahaab F, Chitraselvi RPE. Evaluation of wound healing activity of Acacia caesia in rats. Wound Medicine. $2014 ; 7: 1-7$.

27. Nayak SB, Pinto Pereira LM Catharanthus roseus flower extract has wound healing activity in Sprague Dawley rats. Complement Altern Med. 2006;6(1):41.

28. Fikru A, Makonnen E, Eguale T, Debella A, Mekonnen GA. Evaluation of in vivo wound healing activity of methanolic extract of Achyranthus aspera L. J Ethnopharmacol. 2012;143(2):469-74.

29. David ET, Nnanga N, Bella NMT, Mballa TB, DimoT. Evaluation of the antioxidant activity and the healing action of the ethanol extract of Calotropis procera bark against surgical wounds. J Intercult Ethnopharmacol. 2015;4(1):64-9.

30. Pawar RS, Toppo FA, Mandloi AS, Shaikh S. Exploring the role of curcumin containing ethanolic extract obtained from Curcuma longa (rhizomes) against retardation of wound healing process by aspirin. Indian J Pharmacol. 2015;47(2):160-6.

\section{SUPPLEMENTARY MATERIAL}

\section{Appendix 1}

Skin irritation studies of the standardized ethanolic extract of C. cainito leaves showing Primary Irritation Index

\begin{tabular}{|c|c|c|c|c|c|c|c|}
\hline \multirow{3}{*}{$\begin{array}{l}\text { Rabbit } \\
\text { ID No. }\end{array}$} & \multicolumn{6}{|c|}{ Total erythema + edema } & \multirow{3}{*}{$\begin{array}{c}\text { Average as primary } \\
\text { irritation index }\end{array}$} \\
\hline & \multicolumn{2}{|c|}{$24 \mathrm{~h}$} & \multicolumn{2}{|c|}{$48 \mathrm{~h}$} & \multicolumn{2}{|c|}{$72 \mathrm{~h}$} & \\
\hline & Control & Test & Control & Test & Control & Test & \\
\hline $\mathrm{R}-01$ & 0 & 0 & 0 & 0 & 0 & 0 & 0 \\
\hline R-02 & 0 & 0 & 0 & 0 & 0 & 0 & 0 \\
\hline R-03 & 0 & 0 & 0 & 0 & 0 & 0 & 0 \\
\hline Mean & 0 & 0 & 0 & 0 & 0 & 0 & 0 \\
\hline
\end{tabular}

\section{Appendix 2}

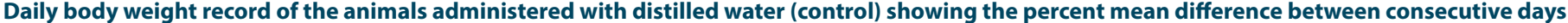

\begin{tabular}{|c|c|c|c|c|c|c|c|c|c|c|c|c|c|c|c|}
\hline \multirow{2}{*}{ Animal no. } & \multicolumn{15}{|c|}{ Body weight on different days (g) } \\
\hline & 0 & 1 & 2 & 3 & 4 & 5 & 6 & 7 & 8 & 9 & 10 & 11 & 12 & 13 & 14 \\
\hline Mean $(n=5)$ & 222.6 & 223.8 & 224.4 & 223.8 & 228.0 & 227.2 & 228.4 & 230.2 & 229.4 & 229.4 & 230.8 & 232.2 & 233.0 & 232.8 & 234.8 \\
\hline SE & 2.52 & 2.33 & 3.01 & 2.75 & 2.88 & 2.06 & 2.50 & 1.85 & 2.18 & 1.66 & 2.08 & 1.85 & 2.17 & 1.93 & 2.58 \\
\hline $\begin{array}{l}\% \text { Mean } \\
\text { difference }\end{array}$ & -- & 0.54 & 0.27 & -0.27 & 1.88 & -0.35 & 0.53 & 0.79 & -0.35 & 0.00 & 0.61 & 0.61 & 0.34 & -0.09 & 0.86 \\
\hline
\end{tabular}

Daily body weight record of the animals administered with the standardized ethanolic extract of $C$. cainito leaves at 2000 mg/kg body weight (test) showing the percent mean difference between consecutive days

\begin{tabular}{|c|c|c|c|c|c|c|c|c|c|c|c|c|c|c|c|}
\hline \multirow{2}{*}{ Animal no. } & \multicolumn{15}{|c|}{ Body weight on different days (g) } \\
\hline & 0 & 1 & 2 & 3 & 4 & 5 & 6 & 7 & 8 & 9 & 10 & 11 & 12 & 13 & 14 \\
\hline Mean $(n=5)$ & 228.0 & 230.0 & 228.0 & 226.6 & 228.6 & 229.4 & 230.0 & 230.6 & 231.0 & 232.4 & 233.2 & 234.6 & 235.6 & 237.2 & 237.6 \\
\hline SE & 0.84 & 0.45 & 0.71 & 0.40 & 0.60 & 0.68 & 0.55 & 0.51 & 0.63 & 0.51 & 0.37 & 0.60 & 0.51 & 0.58 & 0.51 \\
\hline $\begin{array}{c}\% \text { Mean } \\
\text { difference }\end{array}$ & -- & 0.88 & -0.87 & -0.61 & 0.88 & 0.35 & 0.26 & 0.26 & 0.17 & 0.61 & 0.34 & 0.60 & 0.43 & 0.68 & 0.17 \\
\hline
\end{tabular}


SHAILAJAN AND GURJAR: Chrysophyllum cainito L. leaves as potential wound healing agent

Daily food intake record of the animals administered with distilled water (control) and the standardized ethanolic extract of $C$. cainito leaves at $2000 \mathrm{mg} / \mathrm{kg}$ body weight (test) showing the percent difference between consecutive days

\begin{tabular}{|c|c|c|c|c|c|c|c|c|c|c|c|c|c|c|c|}
\hline \multirow{2}{*}{$\begin{array}{l}\text { Treatment } \\
\text { group }\end{array}$} & \multirow{2}{*}{ Parameters } & \multicolumn{14}{|c|}{ Different days } \\
\hline & & 1 & 2 & 3 & 4 & 5 & 6 & 7 & 8 & 9 & 10 & 11 & 12 & 13 & 14 \\
\hline \multirow{2}{*}{ Control } & Food intake $(\mathrm{g})^{*}$ & 62.5 & 65 & 64 & 62.5 & 65 & 67.5 & 70 & 67 & 66.5 & 68 & 70 & 71.5 & 70 & 70 \\
\hline & \% Difference & & 4.00 & -1.54 & -2.34 & 4.00 & 3.85 & 3.70 & -4.29 & -0.75 & 2.26 & 2.94 & 2.14 & -2.10 & 0.00 \\
\hline \multirow{2}{*}{ Test } & Food intake $(\mathrm{g})^{*}$ & 74 & 72.5 & 74 & 76.5 & 77 & 75.5 & 77.5 & 78 & 76.5 & 76 & 78.5 & 78 & 79.5 & 80 \\
\hline & \% Difference & & -2.03 & 2.07 & 3.38 & 0.65 & -1.95 & 2.65 & 0.65 & -1.92 & -0.65 & 3.29 & -0.64 & 1.92 & 0.63 \\
\hline
\end{tabular}

${ }^{*}$ As animals of respective groups were kept in separate cages, record of food intake was cumulative for all the animals $(\mathrm{n}=5)$ of respective group.

Daily water intake record of the administered with distilled water (control) and the standardized ethanolic extract of $\mathrm{C}$. cainito leaves at $2000 \mathrm{mg} / \mathrm{kg}$ body weight (test) showing the percent difference between consecutive days

\begin{tabular}{|c|c|c|c|c|c|c|c|c|c|c|c|c|c|c|c|}
\hline \multirow{2}{*}{$\begin{array}{c}\text { Treatment } \\
\text { group }\end{array}$} & \multirow{2}{*}{ Parameters } & \multicolumn{14}{|c|}{ Different days } \\
\hline & & 1 & 2 & 3 & 4 & 5 & 6 & 7 & 8 & 9 & 10 & 11 & 12 & 13 & 14 \\
\hline \multirow{2}{*}{ Control } & Water intake $(\mathrm{mL})^{*}$ & 95 & 95 & 90 & 95 & 90 & 95 & 90 & 95 & 100 & 105 & 100 & 105 & 110 & 110 \\
\hline & \% Difference & & 0.00 & -5.26 & 5.56 & -5.26 & 5.56 & -5.26 & 5.56 & 5.26 & 5.00 & -4.76 & 5.00 & 4.76 & 0.00 \\
\hline \multirow{2}{*}{ Test } & Water intake $(\mathrm{mL})^{*}$ & 100 & 105 & 100 & 100 & 105 & 100 & 95 & 100 & 105 & 105 & 110 & 115 & 120 & 115 \\
\hline & \% Difference & & 5.00 & -4.76 & 0.00 & 5.00 & -4.76 & -5.00 & 5.26 & 5.00 & 0.00 & 4.76 & 4.55 & 4.35 & -4.17 \\
\hline
\end{tabular}

${ }^{*}$ As animals of respective groups were kept in separate cages, record of food intake was cumulative for all the animals $(\mathrm{n}=5)$ of respective group.

Data on mortality record, mortality latency and cage side observation during acute oral toxicity study of the standardized ethanolic extract of C. cainito leaves for fourteen days

\begin{tabular}{|c|c|c|c|c|}
\hline $\begin{array}{c}\text { Treatment } \\
\text { group }\end{array}$ & Sample details & $\mathrm{D} / \mathrm{T}$ & $\begin{array}{l}\text { Mortality } \\
\text { latency* }\end{array}$ & $\begin{array}{l}\text { Symptoms } \\
\text { of toxicity** }\end{array}$ \\
\hline Control & Administered with distilled water & $0 / 5$ & -- & $\begin{array}{c}\text { No toxic } \\
\text { symptoms }\end{array}$ \\
\hline Test & Administered with the standardized ethanolic extract of C. cainito leaves at $2000 \mathrm{mg} / \mathrm{kg}$ body weight & $0 / 5$ & -- & $\begin{array}{c}\text { during the } \\
\text { observation } \\
\text { period }\end{array}$ \\
\hline
\end{tabular}

Appendix 3

Comparative qualitative histopathological evaluation of the granulation tissue excised on $5^{\text {th }}$ day post wounding

\begin{tabular}{|c|c|c|c|c|c|c|c|}
\hline \multirow{2}{*}{ Parameters } & \multicolumn{7}{|c|}{ Groups } \\
\hline & NC & VC & $\mathrm{CCL}$ & $\mathrm{CCM}$ & $\mathrm{CCH}$ & JT & BTD \\
\hline Fibroplasia & + & + & + & ++ & +++ & +++ & +++ \\
\hline Collagenization & - & - & ++ & ++ & +++ & +++ & +++ \\
\hline Neovascularization & - & - & - & - & - & - & - \\
\hline Leucocytic infiltration & + & ++ & ++ & ++ & +++ & +++ & ++ \\
\hline Epithelialization & +++ & +++ & +++ & +++ & +++ & +++ & +++ \\
\hline
\end{tabular}

Minimal (+), Mild (++), Moderate (+++), Marked (++++). NC: Normal/ untreated control, VC: Vehicle control (base), CCL: Low dose of the standardized ethanolic extract of C. cainito leaves (2.5\%), CCM: Mid dose of the standardized ethanolic extract of C. cainito leaves (5\%), CCH: High dose of the standardized ethanolic extract of C. cainito leaves (20\%), JT: Jatyadi Taila (traditional drug), BTD: Betadine (modern drug). 